\title{
Evaluation of Total Phenolic and Flavonoids Content and their Relation with Antioxidant Properties of Tagetes patula Varieties, Through DPPH Assay
}

\author{
D. Kushwaha*, Y. Verma, P. W. Ramteke and V. M. Prasad \\ Department of Biochemistry and Biochemical Engineering, Sam Higgin Bottom University of \\ Agriculture, Technology and Sciences (SHUATS), Allahabad-211007, India \\ *Corresponding author
}

\section{A B S T R A C T}

Active phytochemicals properties in Tagetes species. Bioactive phenolic compounds and act as a powerful antioxidant, known to found in medicinal and ornamental plants like Tagetes, belong to Asteraceae family. The observed TPC results in the range of (highest to

\section{Keywords}

Antioxidants, Tagetespatula, DPPH, Phenol, flavonoids

Article Info

Accepted:

18 January 2020

Available Online:

10 February 2020 lowest) alcoholic and water extract of Disco yellow variety (86.33mg \& $78.65 \mathrm{mgGAE}$ ), Honey comb variety $(82.00 \mathrm{mg} \& 77.00 \mathrm{mg}$ GAE), Butter Scotch $(79.65 \mathrm{mg} \& 71.65 \mathrm{mg}$ GAE), Aurora orange (72.12 $\mathrm{mg} \& 68.67 \mathrm{mg}$ GAE).TFC was observed in the range of (highest to lowest)alcoholic and water extract of Disco yellow variety $(38.0 \mathrm{mg} \& 23.53$ $\mathrm{mg}$ QE), Honey comb variety (35.67 $\mathrm{mg} \mathrm{\& 20.66} \mathrm{mg} \mathrm{QE),} \mathrm{Aurora} \mathrm{orange} \mathrm{(33.23} \mathrm{mg} \&$ $19.67 \mathrm{mgQE}$ ), Butter Scotch (31.46 mg \&17.89 mg QE).In a more elaborate way, it could be more understandable by regression analysis demonstrate the water extracted phenolic compounds contribute maximum value i.e. about $95 \%$ (at $P<0.05$ ) while methanolic extracted phenolics contribute about $92 \%$ (at $P<0.05$ ) of radical scavenging properties. All the experiments were conducted in triplicate manner for the determination of total phenolics, total flavonoids, and antioxidant properties using DPPH assay. All the values are expressed as mean \pm standard deviation (SD). No Significant differences were observed in the value of correlation coefficient to define the efficacy of water and methanolic extract. The purpose of the current study is to investigate the antioxidant activity of Tagetes patula leaves.

\section{Introduction}

Now a days, lots of herbaceous plants have been discovered, with active phytochemicals properties crucial for many biological activities such as antimicrobial, antiinflammatory, antioxidant and utilized as health promoting products (Achilonu et al., 2018; Mehtab et al., 2014; Ouelbani et al.,
2016). Because of many cosmetic applications found in herbs, and their different organs of plant have antioxidant and antiinflammatory activities, preventing from aging or whitening problems of skin (Forni et al., 2019). These activities are characterized by the presence of bioactive phenolic compounds and act as a powerful antioxidant, known to found in medicinal and ornamental 
plants like Tagetes, belong to Asteraceae or Compositae family (Martha et al., 2006). Tagetes species commonly known as marigold an herb. Tagetes is a genus of annual and perennial herbaceous plant, normally grows as a wild and common garden plant throughout Europe and North\& South America especially in Mexico, but nowadays, many species grow in tropics and subtropics region of Asian countries mainly in India and Bangladesh (Kadam et al., 2013), even found in all around the world.

The genera name Tagetes encode 33 Tagetes species, five of which have been introduced in an Indian garden viz. T. erecta L., T. minuta L., T. patula L., T. lucida and T. tenuifolia (Kushwaha and Verma, 2017). Amongst these medicinal plants: (French marigold) T. patula $L$. is an aromatic annual herb belongs tothe family Asteraceae (Ramakrishnan et al., 2015). T. patula L. herbaceous plant, possesses various biological properties including nematicidal (Faizi et al., 2011a), antibacterial, antifungal (Faizi et al., 2008), anti-inflammatory (Kasahara et al., 2002), analgesic, and antioxidant (Faizi et al., 2011b). Several bioactive constituents found in T. patula L. i.e. carotenoids (hence the orange colour), essential oils, flavonoids, sterols, tannins, saponins, triterpene alcohols, polysaccharides (Cetkovic et al., 2003). Especially, the presence of the secondary metabolites was responsible for the specific kind of fragrance in Tagetes plants (Randon et al., 2006; Hemali and Sumitra, 2014). In addition, secondary metabolites presence has an important role in biological and pharmacological activities such as antioxidative, anti-allergic, anti-carcinogenic, antimicrobial and hypoglycemic etc. (Stankovic, 2011). Antioxidants are free radical capturing compounds. It may protect cells from the damaging action of unstable free radicals' species (Hamid et al., 2010; Stankovic, 2011). Natural antioxidant, which are obtained from plants are greater benefit in comparison to the synthetic (Rohman et al., 2010)antioxidants such asbutylated hydroxy anisole (BHA), butylated hydroxy toluene (BHT), propyl gallate and tertiary butyl hydroquinone (Subhashini et al., 2010). Previously reported phytochemical studies of $T$. patula suggested the presence of flavonoids and terpenes (Isman, 2006; Pavela, 2007). Tagetes species declare as a therapeutic medicinal plant to treat various kind of diseases such as colic, diarrhoea, vomit, fever, cancer, hepatic and inflammatory disorders even in arthritis (Vedam et al., 2019; Kushwaha and Verma, 2017). The purpose of the current study is to investigate the antioxidant activity of Tagetes patula leaves, collected from Agricultural fields of SHUATS, Prayagraj.

\section{Materials and Methods}

\section{Plant material}

The samples of Tagetes patula L., were collected in October to November from the field of SHUATS, Allahabad.

\section{Extraction of the plant material}

Fresh plant samples (1g) were collected and washed properly under running water to remove the dust. Samples were grinded by using the motor and pastel and collected the extract after the centrifugation of the sample at $12,000 \mathrm{rpm}$ for $15 \mathrm{~min}$.

\section{Total phenolic contents}

Total phenolic compounds extraction was done in methanolic and water solvents and spectrophoto metrically estimated by using the Folin-Ciocalteu reagent (FCR) and the results are expressed as of gallic acid equivalents per $\mathrm{g}$ fresh weight (Kushwaha and Verma, 2017). 


\section{Total flavonoid contents}

Total flavonoids content (expressed as mg quercetinperg fresh weight) were estimated in different leaves extracts of $T$. patula varieties i.e. (leaves extraction by methanol and water solvents) and their estimation was done by spectrophoto metrically according to Kushwaha and Verma (2017).

Evaluation of DPPH (2,2-diphenyl-1picrylhydrazyl) Radical Scavenging Assay

Radical scavenging activity of Tagetes sp.was determined by following the method (Siddhu and Saxena, 2017).First of all, Prepare the $0.1 \mathrm{mM}$ of DPPH solution and made the extract of different concentration $(25 \mu \mathrm{g} / \mathrm{ml}$, $50 \mu \mathrm{g} / \mathrm{ml}$ and $100 \mu \mathrm{g} / \mathrm{ml}$ ) separately. The prepared reaction mixture contains the equal amount of DPPH solution and Tagetes extract, then incubate it for $30 \mathrm{~min}$. at room temperature. The absorbance was recorded at $517 \mathrm{~nm}$ against the ascorbic acid and BHT as standard. Free radical scavenging activity was calculated by using following equation:

Inhibition $\%=\left(\mathrm{A}_{\mathrm{DPPH}}-\mathrm{A}\right.$ sample $) / \mathrm{A}_{\mathrm{DPPH}} \times 100$

\section{Statistical analysis}

All the experiments were conducted in triplicate manner for the determination of total phenolics, total flavonoids, and antioxidant properties using DPPH assay. All the values are expressed as mean \pm standard deviation (SD).Significant differences were expressed by Correlation coefficients $(r)$ and coefficients of determination $\left(r^{2}\right)$ by using Microsoft Excelvers. 2010.

\section{Results and Discussion}

Since the antioxidant compounds found in plants have different polarities, different solvents are used to isolate antioxidants.
Water, methanol, ethanol, and acetone commonly used solvents in extraction processes (Ngo et al., 2017). Phenols are very important plant constituents because of their scavenging ability for free radicals due to their hydroxyl groups presence. Hence, the phenolic compounds may be a main contributor of antioxidant action (Tosun et al., 2009).

The TPC \& TFC presence in the extracted samples and its yield depends on the selected solvent. The results of total phenolic and total flavonoid content were shown in Table 1. The results showed that the all plants varieties are rich sources of phenolics. TPC results were expressed as mg of gallic acid equivalent per gram fresh weight (mgGAE/100g). The observed TPC results in the range of (highest to lowest) alcoholic and water extract of Disco yellow variety $(86.33 \mathrm{mg} \& 78.65$ mgGAE), Honey comb variety $(82.00 \mathrm{mg}$ \&77.00mg GAE), Butter Scotch (79.65 mg \& $71.65 \mathrm{mg}$ GAE), Aurora orange (72.12 mg \& $68.67 \mathrm{mg}$ GAE). Similar finding was observed by Kushwaha and Verma (2017), reported $30 \mathrm{mg} \mathrm{GAE} / \mathrm{g}$ and $80 \mathrm{mg} \mathrm{GAE} /$ gcontent was found in aerial part (flower and leaves respectively) of $T$. patula while highest phenolic content was reported in methanolic extract $(49.764 \mathrm{mg} \mathrm{GAE} / \mathrm{g}$ ) of $T$. erecta flower and lowest content was found in chloroform extract (15.450) by Siddhu and Sexena (2017).

TFC was observed in the range of (highest to lowest) alcoholic and water extract of Disco yellow variety $(38.0 \mathrm{mg} \& 23.53 \mathrm{mg} \mathrm{QE})$, Honey comb variety $(35.67 \mathrm{mg} \& 20.66 \mathrm{mg}$ QE), Aurora orange $(33.23 \mathrm{mg} \&$ 19.67mgQE), Butter Scotch (31.46 mg $\& 17.89 \mathrm{mg}$ QE). Previously reported studies confirm that the phenolics compounds had antioxidant and free radical species scavengers' properties supported by (Huyut $e t$ al., 2017; Leopoldini et al., 2017). Phenolics 
antioxidants act as reducing agents, hydrogen donors and reactive oxygen capturer (Kasote et al., 2015).Instead of antioxidant property, phenolics compounds gaining more interest among researchers because of nutritious values, actually, derived from naturally agricultural crops and vegetables (Krishnaiah et al., 2011).

In addition to this, these compounds impart stabilizing nature to biological membrane lipids against peroxidation and stops the reactive oxidizing enzymes (Kurutas,2016; Parthasarathy et al., 2009). An effective reason behind this antioxidant activity, is to provide a stability to a cellular membrane by phenolics compounds such as flavonoids, its structure altered and their functional groups substitution mainly-OH groups and other groups contribute also, thereby, affecting flavonoids antioxidant properties (Forni et al., 2019).
DPPH is a colorimetric assay, consider as efficient and best method to find out the radical scavenging activity of a concoctive antioxidant species compare to other methods. Basic principle of DPPH assay is antioxidants captures the DPPH radicals by donating the hydrogen and convert it into reduced from of DPPH-H (Aksoy et al., 2013; Sahu et al., 2013). When DPPH-H a reduced form formed, its color changes from purple to yellowish, which is recorded at $517 \mathrm{~nm}$ by spectrophotometrically. Using DPPH assay, free radical scavenging activity of $T$. patula extract was determined, through which $50 \%$ inhibition concentration (IC50) of radicals was calculated. Obtained IC50 value of $T$. patula extract was in the range of $39.732 \mu \mathrm{g} / \mathrm{ml}$ to $16.665 \mu \mathrm{g} / \mathrm{ml}$, as shown in a Table 2.

Table.1 Comparison between the Total phenolic (mgGAE/100 g) and Total Flavonoids content (mg QE/100 g) extraction from different varieties of $T$. patula

\begin{tabular}{|c|c|c|c|c|}
\hline $\begin{array}{c}\text { Tagetuspatula } \\
\text { Varieties }\end{array}$ & $\begin{array}{c}\text { Total phenolic } \\
\text { compound } \\
\text { (TPC)mg } \\
\text { GAE/100 g }\end{array}$ & $\begin{array}{c}\text { Total phenolic } \\
\text { compound } \\
\text { (TPC)mg GAE/100 g }\end{array}$ & $\begin{array}{c}\text { Total Flavonoids } \\
\text { compound } \\
\text { (TFC)mg QE/100 g }\end{array}$ & $\begin{array}{c}\text { Total Flavonoids } \\
\text { compound } \\
\text { (TFC)mg QE/100 g }\end{array}$ \\
\cline { 2 - 5 } & $\begin{array}{c}\text { Methanolic extract } \\
\text { Mean } \pm \text { S.D }\end{array}$ & $\begin{array}{c}\text { Water extract } \\
\text { Mean } \pm \text { S.D }\end{array}$ & $\begin{array}{c}\text { Methanolic extract } \\
\text { Mean } \pm \text { S.D }\end{array}$ & $\begin{array}{c}\text { Water extract } \\
\text { Mean } \pm \text { S.D }\end{array}$ \\
\hline HC & $82 \pm 0.45$ & $77.0 \pm 0.29$ & $35.67 \pm 0.29$ & $20.66 \pm 0.86$ \\
\hline DY & $86.33 \pm 0.21$ & $78.65 \pm .0 .26$ & $38.0 \pm 0.24$ & $23.53 \pm 0.76$ \\
\hline BS & $79.65 \pm 0.22$ & $71.11 \pm 0.39$ & $31.46 \pm 0.19$ & $17.89 \pm 0.77$ \\
\hline AO & $72.12 \pm 0.16$ & $68.67 \pm 0.25$ & $33.23 \pm 0.21$ & $19.67 \pm 0.72$ \\
\hline
\end{tabular}

Butter Scotch: BS, Honey comb HC, Disco yellow DY, Aurora orange: AO

Table.2 DPPH \% inhibition in Tagetuspatulavarieties

\begin{tabular}{|c|c|}
\hline Tagetuspatulavarieties & DPPH(\%) of inhibition \\
\hline HC & 35.975 \\
\hline DY & 39.732 \\
\hline BS & 16.665 \\
\hline AO & 36.332 \\
\hline
\end{tabular}

Butter Scotch: BS, Honey comb HC, Disco yellow DY, Aurora orange: AO 
Fig.1 Correlation between antioxidant activity and water extracted total phenolic content of T. patula varieties

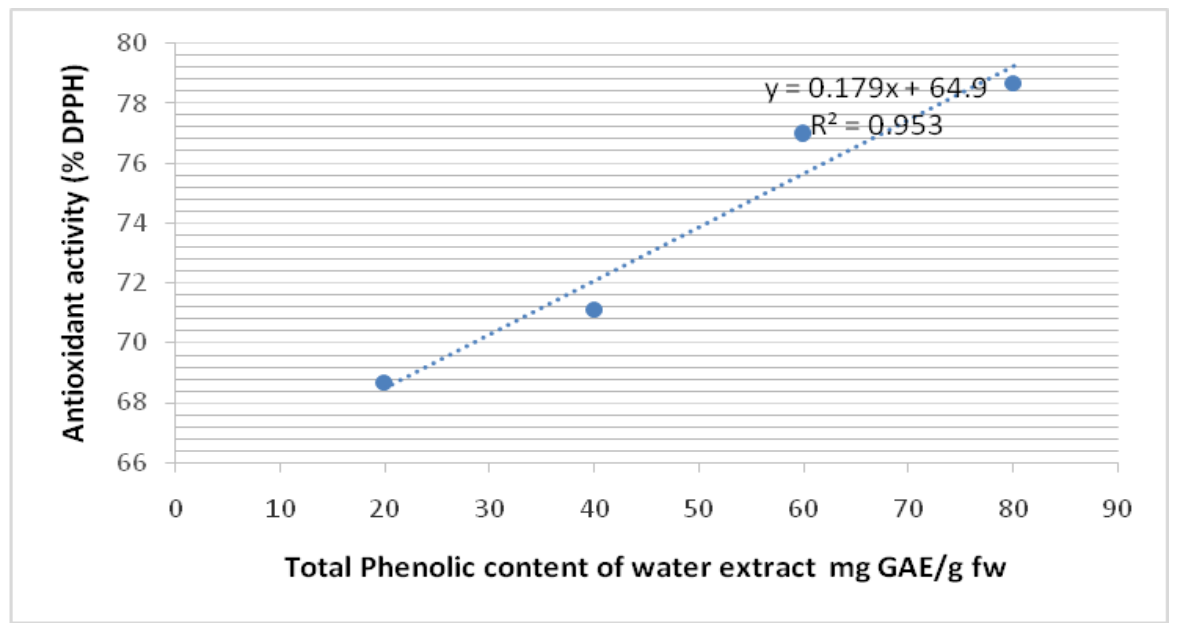

Fig.2 Correlation between antioxidant activity and water extracted total phenolic content of T. patula varieties

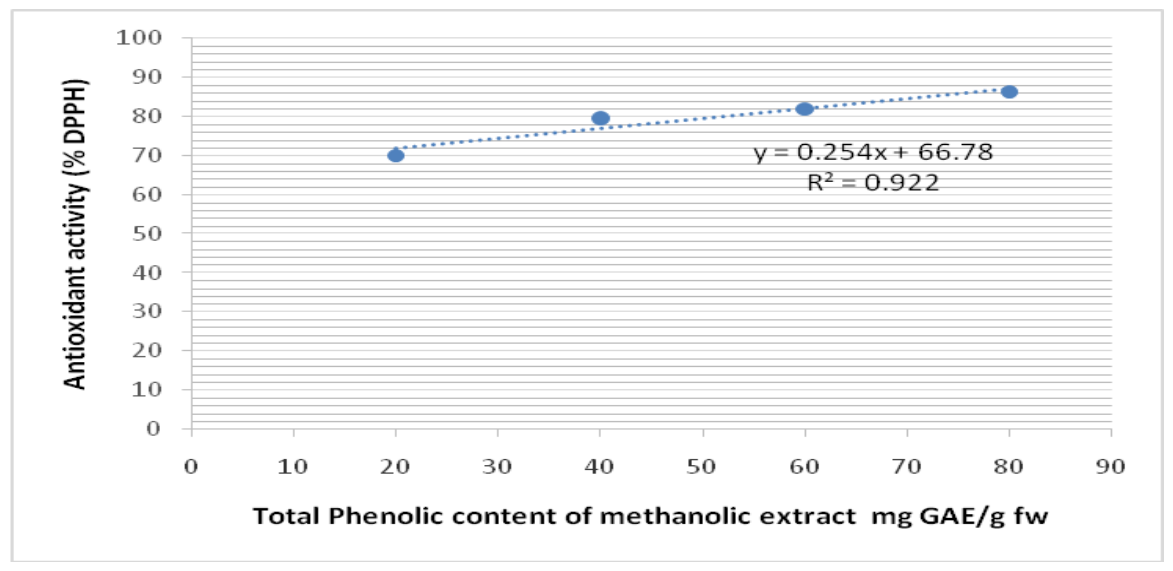

The obtained results showed the relation between the antioxidant activity and phenolic content determined by using the DPPH assay applied on $T$. patula varieties extract as shown in Figures 1 and 2, respectively. In a more elaborate way, it could be understandable by regression analysis demonstrate the water extracted phenolic compounds contribute maximum value i.e. about $95 \%\left(r^{2}=0.9537\right.$ at $\left.P<0.05\right)$ while methanolic extracted phenolics contribute about $92 \%\left(r^{2}=0.9222\right.$ at $\left.P<0.05\right)$ of radical scavenging properties respectively as shown in (Fig. 1, 2). Remaining antioxidant property is contributed by other non-phenolics compounds such as vitamins and carotenoids (Pourmorad et al., 2006). The major antioxidants compounds like phenolics and flavonoids plays as a primary antioxidant (Chang et al., 2002; Kulma et al., 2014)because it is known to react with $-\mathrm{OH}$, $\mathrm{O}_{2}{ }^{-2}$ and lipid peroxide reactive species (Munhoz et al., 2014; Kushwah and Verma 2017). These antioxidant species are known to protect the DNA from oxidative stress, inhibit the tumoric cell growth, and had antiinflammatory and antimicrobial activities as well. Present study was supported by Yao et 
al., (2010), there study showed the significant difference between the antioxidant activity, total phenolics and total flavonoids content found in celery and set correlation $r$ value was positive, it means there was a direct relation between them.

This study concludes the highest phenolic and flavonoid content was observed in DY variety compare to other variety of Tagetes patula. It means DY variety had more antioxidant property. In this study, water and methanolic extract of Tagetes was compared in terms of efficacy to extract out phenolic and flavonoids compounds to a greater extent. Statistically, no significant differences were observed in the value of correlation coefficient to define the efficacy of water and methanolic extract.

\section{Acknowledgement}

The authors are thankful to Prof. J.B. Lall, Dean, JIBB, SHUATS providing necessary facilities to carry out the experimental work.

Conflict of Interest: No conflict of interest

\section{References}

Achilonu M, Shale K, Arthur G, Naidoo K, Mbatha M (2018). Phytochemical Benefits of Agroresidues as Alternative Nutritive Dietary Resource for Pig and Poultry Farming. JChem. 2013: 1-16.

Aksoy L, Kolay E, AgiloniiY, Aslan Z, Kargioglu M (2013). Free radical scavenging activity, total phenolic content, total antioxidant status, and total oxidant status of endemic Thermopsis turcica. Saudi J Bio. Sciences. 20(2013), 235-239.

Cetkovic, G.S., Dilas, S.M., CanadanovicBrunrt J.M., Tumbas V.T. (2003). Thin layer chromatograpy analysis and scavenging activity of marigold (Calendula officinalis L.) extracts. APTEFF. 34: 93- 102.

Chang C, Yang M, Wen H, Chern J (2002). Estimation of total flavonoids content in propolis by two complementary colorimetric methods. J Food and Drug Ana. 10:178-182.

Faizi S, Dar A, Siddiqi H, et al., (2011b). Bioassay guided isolation of antioxidant agents with analgesic properties from flowers of Tagetes patula. Pharm Biol. 4:516-25.

Faizi S, Fayyaz S, Bano S, et al., (2011a). Isolation of nematicidal compounds from Tagetes patula $L$. yellow flowers: Structure-activity relationship studies against cyst nematode Heteroderazeae infective stage larvae. J Agric Food Chem. 59:9080-93.

Faizi S, Siddiqi H, Naz A, et al., (2008). Antibacterial and antifungal activities of different parts of Tagetes patula: Preparation of patuletin derivatives. Pharm Biol 46:309-20.

Forni C, Facchiano F, Bartoli M, Pieretti S, Facchiano A, Arcangelo D, Norelli S, Valle G, Nisini R, Beninati S, Tabolacci C, Jadeja RN (2019). Beneficial Role of Phytochemicals on Oxidative Stress and Age-Related Diseases. BioMed Res Inter. 2019:1-16

Hamid A.A., Aiyelaagbe O.O., Usman L.A., Ameen O.M., Lawal A (2010). Antioxidants: Its medicinal and pharmacological applications. Afri $J$ Pure and Appl chem. 4(8): 142-151.

HemaliP, Sumitra C (2014). Evaluation of antioxidant efficacy of different fractions of Tagetes erecta L. Flowers. IOSR J Pharm Bio Sci. 9(5): 28-37.

Huyut Z, Beydemir F, Gulcin E (2017). Antioxidant and Antiradical Properties of Selected Flavonoids and Phenolic 
Compounds. Bioche Res Inter.2017: 1-11.

Isman, M.B. (2006). Botanical insecticides, deterrent and repellant in modern agriculture and increasingly regulated world. Annu. Rev. Entomol., 51: 4566.

Kadam P V, Bhingare C L, Sumbe R B, Nikam R Y, Patil M J (2013). Pharmacognostic, Physiochemical and Phytochemical Investigation of Tagetes erecta Linn flowers (Asteraceae). JBSO. 1(1):21-4.

Kasahara Y, Yasukawa K, Kitanaka S, et al., (2002). Effect of methanol extract from flower petals of Tagetes patula $L$. on acute and chronic inflammation model. Phyt Res. 16:217-22.

Kasote DM, Katyare SS, Hegde MV, Bae H (2015). Significance of Antioxidant Potential of Plants and its Relevance to Therapeutic Applications. Int J Bio Sci. 11(8): 982-991.

Krishnaiah D, Sarbatly R, Nithyanandam R (2011). A review of the antioxidant potential of medicinal plant species. Food BioproPro.89:217-33

Kulma A, Kostyn K, MierziakJ(2014). Flavonoids as Important Molecules of Plant Interactions with the Environment. Mole. 19(10): 16240 16265.

Kurutas EB (2016). The importance of antioxidants which play the role in cellular response against oxidative/nitrosative stress: current state. Nutri J. 15 (71):1-22

Kushwaha D. and Verma Y (2017).Evaluation of Antioxidant and Free Radical Scavenging Activity of Tagetes patula. Annual Res Review Bio. 13(6): (2017),1-8.

Leopoldini M, Russo N, Toscano M (2011). The Molecular Basis of Working Mechanism of Natural Polyphenolic
Antioxidants. Food Chem. 125:288306

Martha R, Gutierrez P, Luna HH, Garrido SH (2006). Antioxidant activity of Tagetes erecta essential oil. J Chil Chem Soc. 51(2): 883-886

Mehtab P, Ali MM, Mahbbob A, Faheem A, Pedro SPS, Manuela RS (2014). Two new phenolic compounds from Ficusrumphii and their antiproliferative activity. $J$ Nat Prod Res. 28: 646-652.

MunhozVM, Longhini R, Souza JRP, Zequi JAC, Mello EVS, Lopes GC, J.C.P. Mello JCP (2014).Extraction of flavonoids from Tagetes patula: process optimization and screening for biological activity. Revi Brasileira Farmaco. 24: 576-583

Ngo T V, Scarlett C J, Bowyer M C, Ngo P D, Vuong QV (2017). Impact of Different Extraction Solvents on Bioactive Compounds and Antioxidant Capacity from the Root of Salacia chinensis L. J Food Quality .2017: 1-9.

Ouelbani R, Bensari S, Mouas TN, and Khelifi D (2016). Ethnobotanical investigations on plants used in folk medicine in the regions of Constantine and Mila (North-East of Algeria). $J$. Ethnopharmacol. 194: 196-218

Parthasarathy S., Azizi J.B., Ramanathan,S., Ismail S., Sasidharan S., Ikram M. Said, M. and Mansor S.M. (2009). Evaluation of antioxidant and antibacterial activities of aqueous, methanolic and alkaloid extracts from Mitragynaspeciosa (rubiaceae family) leaves. Mole. 14: 3964-3974.

Pavela, R. (2007). Possibilities of botanical insecticide exploitation in plant protection. Pest. Tech., 1: 47-52.

Pourmorad F., Hosseinimehr S.J., Shahabimajd N. (2006). Antioxidant activity, phenol and flavonoid contents 
of some selected Iranian medicinal plants. Afrri J Biotech. 5 (11): 11421145.

Ramakrishnan P, Chandrasekhar T, Muralidharan P (2015). Cognitive enhancing, anti-acetylcholinesterase, and antioxidant properties of Tagetes patula on scopolamine-induced amnesia in mice. Interl $J$ Green Pharm9:167-174.

Randon M., Velasco J., Hernandez J., Pecheneda M., Roja P., Morales A., Carmon J., Diaz T. (2006). Chemical composition and antibacterial activity of the essential oil of Tagetes patula L. (Asteraceae) collected from the Venezuela Andes. Rev. Latinoamer. Quím. 34/1-3: 32-36.

Rohman A., Riyanto S., Yuniarti N., Saputra W.R., Utami R. (2010). Antioxidant activity, total phenolic, and total flavaonoid of extracts and fractions of red fruit (Pandanus conoideus Lam). Int. Food Res. J. 17: 97-106.

Sahu R.K., Kar M., Routrary R. (2013). DPPH free radical scavenging activity of some leafy vegetables used by
Tribals of Odisha, India. J Med Plants Stud. 1(4):21-27.

Siddhu N, Saxena J (2017). Evaluation of Invitro Antioxidant Activity of Flowers of Tagetes erecta. Inter $J$ Pharmaco Phyto Res. 9(7); 975-979

Stankovic M. S. (2011). Total phenolic content, flavonoid concentration and antioxidant activity of Marrubium peregrinum L. extracts. Kragujevac $J$. Sci. 33: 63-72.

Subhashini R., Mahadeva Rao U.S, Sumathi P., and Gunalan G. (2010). A comparative phytochemical analysis of cocoa and green tea. Indian J. Sci. Tech. 3(2): 188-192.

Tosun M, Ercisli S, Sengul M, Ozer H, Polat $\mathrm{T}$ (2009). Antioxidant properties and total phenolic content of eight Salvia species from Turkey. Biol. Res. 41: 175-181.

Vedam V V. A, Xavier A S, David D C (2019). In-vitro Evaluation of Antifungal and Anticancer Properties of Tagetes erecta Petal Extract. Bio Pharm J. 12(2): 815-823.

\section{How to cite this article:}

Kushwaha, D., Y. Verma, P. W. Ramteke and Prasad, V. M. 2020. Evaluation of Total Phenolic and Flavonoids Content and their Relation with Antioxidant Properties of Tagetes patula Varieties, Through DPPH Assay. Int.J.Curr.Microbiol.App.Sci. 9(02): 2356-2363. doi: https://doi.org/10.20546/ijcmas.2020.902.268 